\title{
Phytosynthesis, Characterization and Antimicrobial Activity of Iron Oxide Nanoparticle using Henna (Lawsonia Inermis)
}

\author{
Dr. C. M. Noorjahan \\ Assistant Professor, PG \& Research Department of Zoology, \\ Justice Basheer Ahmed Sayeed College for Women (Autonomous), Teynampet, Chennai- 600018
}

\begin{abstract}
Nanotechnology is the most capable technology that can be applied in any field of interest. Technology has created an impressive increase in the production of nanomaterial in many sector of the society. The biosynthesis of nanoparticle is the intersection of nanotechnology and biotechnology that has received increasing attention due to a growing need to develop eco-friendly technologies in material synthesis. Hence an investigation has been carried out to synthesize Iron oxide nanoparticle using Henna leaves (Lawsonia inermis) extract, to study the characterization and antimicrobial activities of it. The results of the green synthesized Iron oxide nanoparticle using Henna leaves extract showed the change of colour from orange to black which may be due to Surface Plasmon Resonance phenomenon. The results of UV analysis of iron oxide nanoparticle revealed the absorbance peak at $425 \mathrm{~nm}$. The results of FTIR analysis revealed the functional groups present in the Iron oxide nanoparticle, displays a number of peaks which reflects the complex nature. The results of XRD analysis showed a high crystallinity of Iron sample level with diffraction angle ranged from $30-80^{\circ}$ at $2 \Theta$. The shape of synthesized iron oxide nanoparticle was found to be hexagonal and size was $2 \mu \mathrm{m}$ in diameter using SEM. The result of antimicrobial activity (bacteria and fungi) of synthesized Iron oxide nanoparticle indicates a potent antimicrobial activity of nanoparticle.
\end{abstract}

Keywords - Henna Leaves Extract; Iron Oxide Nanoparticle; Synthesis; Characterization; Antimicrobial Activity

\section{Introduction}

Nanotechnology is one of the recent technologies which has various application in many fields. Nanoparticle is a particle whose size in the range of $10^{-9} \mathrm{~nm}$. It has unique thermal, electrical, mechanical, optical properties etc. Metal oxide nanoparticle plays a very important role in many areas of chemistry, physics and materials science (Rodriguez et al., 2007). The metal elements are able to form a large diversity of oxide compounds (Wykoff, 1964). Various nanoparticle like $\mathrm{Fe}, \mathrm{Ni}, \mathrm{Co}, \mathrm{Mn}, \mathrm{Zn}$ etc. these metal oxide nanoparticles plays a significant role $\mathrm{n}$ various fields such as pharmaceuticals, industries, biomedical application etc. They are also applicable in other high frequency applications (Willard et al., 2014). Most common ore is haematite (Iron oxide, $\mathrm{Fe}_{2} \mathrm{O}_{3}$ ). Iron oxide nanoparticle is one of the important metallic nanoparticle which possess strong antimicrobial, anticancer, antiinflammatory, analgesic, anti parasitic and virucidal properties (Habbal et al., 2013). Among the different methods of synthesis of Iron oxide nanoparticle, biological method of nanoparticle synthesis specially using plants is cost effective and eco-friendly. One of the most considered methods is production of metal nanoparticle using biological organisms. Nanoparticle produced by plants is more stable and the rate of synthesis is faster than that of microorganisms (Tayyabanaseem et al., 2015)

Henna (Lawsonia inermis) leaf has recently been found to be a potent antioxidant due to high concentrations of Lawson (2 hdroxy-1, 4-naphthoquinone). It contains benzene unit, p-benzoquinone unit and phenolic group, that may be responsible for the reduction and stabilization of metal ions. Hence the present investigation was carried out to synthesize Iron oxide nanoparticle using Henna (Lawsonia inermis) leaves extract, its characterization, antibacterial activity and antifungal activity were studied..

\section{Materials and Methods}

\subsection{Selection of the Plant}

Fresh and healthy Lawsonia inermis (Henna) leaves Maruthani in Tamil, were collected from the henna plant from the locality in around the Chennai. It was ensured that they were healthy, uninfected and they were thoroughly washed and rinsed with sterile distilled water (Plate 1). The fresh leaves of Lawsonia inermis is collected and authenticated by the taxonomist Prof. P. Jayaraman (Certificate No. PARC/2016/3325).

Plate 1. Selection of the Plant -Lawsonia Inermis (Henna)
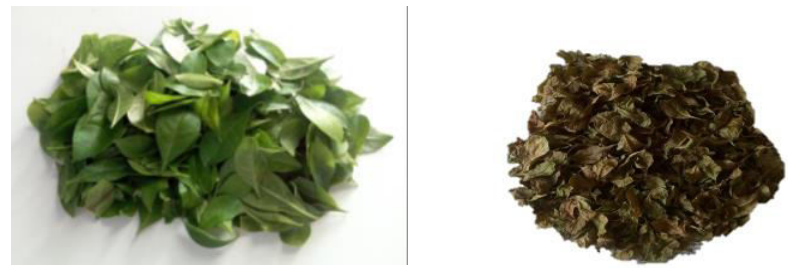

Fig.1: (a) Lawsonia inermis(Henna) leaves (b) Dried leaves 


\subsection{Ferrous Sulphate for Synthesis of Iron Oxide Nanoparticle}

Ferrous sulphate was obtained from Himedia and distilled water was used throughout the process to synthesize the iron oxide nanoparticle.

\subsection{Collection of Bacterial and Fungal Isolates for Antimicrobial Activity of Iron Oxide Nanoparticle}

Clinical bacterial isolates such as Escherichia coli and Staphylococcus aureus and fungi like Aspergillus niger and Mucor sp. were collected from a hospital. Samples were transported to the laboratory for further processing in an ice box.

\subsection{Green Synthesis of Iron Oxide Nanoparticle using} Henna (Lawsonia inermis) Leaves Extract

\subsubsection{Preparation of Aqueous Decoctions}

Preparation of aqueous decoction was done by following the method of Tayyabanaseem et al. (2015). A simple conventional heating method was used in the synthesis of iron nanoparticle (FeNP) by using plant extract. Plant extract was prepared by dissolving $8 \mathrm{gms}$ of the sieved leaf powder in $200 \mathrm{ml}$ of deionized water and the resulting mixture was kept on stirring for 3 hours by using the magnetic stirrer. The resulting solution was kept undisturbed for 1 hour, then filtered and stored for further use.

\subsubsection{Preparation of Ferrous Sulphate Solution for Synthesis of Iron Oxide Nanoparticle}

Preparation of ferrous sulphate solution for synthesis of Iron oxide nanoparticle was carried out by following the procedure of Tayyabanaseem et al. (2015). $30 \mathrm{ml}$ of $0.01 \mathrm{M}$ $\mathrm{FeSO}_{4}$ solution was added to plant extract (filtrate) for every interval of 5 minutes using $8 \mathrm{ml}$ in each interval until $50 \mathrm{ml}$, resulting mixture was stirred at $70^{\circ} \mathrm{C}$. The solution was cooled and the product was separated by centrifugation $(10,000 \mathrm{rpm})$ for 5 minutes. The product was dried at $50^{\circ} \mathrm{C}$ for 3 hours and the dried powder of henna leaves was the iron oxide nanoparticle.

\subsection{Characterization of Green Synthesised Iron Oxide Nanoparticle}

\subsubsection{UV-visible Spectroscopy}

The formation of Iron oxide nanoparticle was confirmed by UV-visible spectroscopy using Beckman-DU spectrophotometer. Size of the iron oxide nanoparticle was analysed with UV-Spectrometer in the range between 410$460 \mathrm{~nm}$.

\subsubsection{Fourier Transform Infrared Spectroscopy}

Fourier Transform Infrared Spectroscopy (FTIR) Spectroscopy was used to investigate the interactions between different species and changes in chemical compositions of the mixtures. The FTIR spectra of iron oxide nanoparticle using Lawsonia inermis leaf powder were recorded in Perkin Elmer spectrum 1 in diffuse reflection mode operating at a resolution of $4 \mathrm{~cm}^{-1}$, recorded between 4000 and $400 \mathrm{~cm}^{-1}$

\subsubsection{X-ray Diffraction}

X-ray Diffraction (XRD) measurement of green synthesized Iron oxide nanoparticle were coated on the slide on a Smart-lab processor generator operated at the voltage of $40 \mathrm{kV}$ and a current of $30 \mathrm{~mA}$ with $\mathrm{Cu} \mathrm{K \alpha 1}$ radiation $(1.5405 \AA)$. The size of the Iron oxide nanoparticle was also determined from X-ray line broadening using the Debye - Scherrer formula.

\subsubsection{Scanning Electron Microscope}

The morphology of Iron oxide nanoparticle was examined by Scanning Electron Microscope (SEM) performed by using Quanta 200-F instrument.

\subsection{Antimicrobial Activity Assay}

\subsubsection{Pure Culture of E. coli and S. aureus}

Human pathogenic gram negative bacteria (Escherichia coli) and gram positive (staphylococcus aureus) bacterial strains are used for antibacterial activity of Iron oxide nanoparticle. Two fungal strains namely Aspergillus niger and Mucor sp. were used for antifungal study of iron nanoparticle by well titre plate method using resazurin micro titre assay method. Subculture of $E$. coli and $S$. aureus were carried out by following the procedure of Sundararaj (1997). E. coli was subcultured using Eosin Methylene Blue agar medium and incubated for 24 hours, then the culture was transferred to Muller Hinton broth and incubated for 1 day which was used for antibacterial activity of Henna leaves extract using titre plate method by following the procedure of Benzie and Strain (1996).

\subsubsection{Pure Culture of A. niger and Mucor sp.}

Subculture of A. niger and Mucor sp. were carried out by following the procedure of Sundararaj (1997). A. niger and Mucor sp.were subcultured using sabouraud dextrose 
agar medium and incubated for 3-4 days then the culture was transferred to nutrient broth and incubated for 1 day which was used for antifungal activity of Henna leaves extract using titre plate method by following the procedure of Benzie and Strain (1996).

The anstimicrobial activity of green synthesized Iron nanoparticle was performed by using 96 well titre plate by following the procedure of Benzie and Strain (1996). The plant extract were evaluated for antimicrobial potential against 2 bacterial strains and 2 fungal strains. The Minimum Inhibitory Concentration (MIC) of plant extract was determined using micro broth dilution assay.

\subsection{Statistical Analysis}

The data obtained from the experiments was analysed and expressed as mean and Standard Deviation, T-test formula and Chi-square test.

\section{Results}

\subsection{Green synthesis of Iron oxide nanoparticle using Henna leaves (Lawsonia inermis)}

The results of green synthesis of Iron oxide nanoparticle using henna leaves (Lawsonia inermis) are presented in the plate 2 . Iron oxide nanoparticle was synthesized successfully by using Henna leaves (Lawsonia inermis) leaf extract. The results of the study showed that during the exposure of leaf extract to ferrous sulphate solution, reduction of iron ions into Iron nanoparticle is monitored as a result of the colour change from orange to black colour, (plate 2) which occurred due to the Surface Plasmon Resonance phenomenon. The metal nanoparticles have free electrons, which helps in the formation of the Surface Plasmon Resonance absorption band.

\subsection{Characterization of green synthesized iron oxide nanoparticle using Henna (Lawsonia inermis) leaves $U V$ - visible spectroscopy}

UV-visible absorbance spectroscopy is a very useful technique for studying metal nanoparticle because the peak positions and shapes are sensitive to particle size. The results of UV analysis of Iron oxide nanoparticle synthesized using henna leaves (Lawsonia inermis) are presented in the figure 1 . The results of UV analysis of Iron oxide nanoparticle synthesized using Henna leaves (Lawsonia inermis) are sensitive to particle size. Absorption spectra of Iron oxide nanoparticle formed in the reaction media has absorbance peak at $425 \mathrm{~nm}$. The reduction of pure Iron to nanoparticle is monitored by measuring the UV-visible spectrum the most confirmatory level for the detection of Surface Plasmon Resonance property (SPR) of Iron nanoparticle.

Plate 2. Synthesis of iron oxide nanoparticle using Lawsonia inermis (Henna) leaves extract
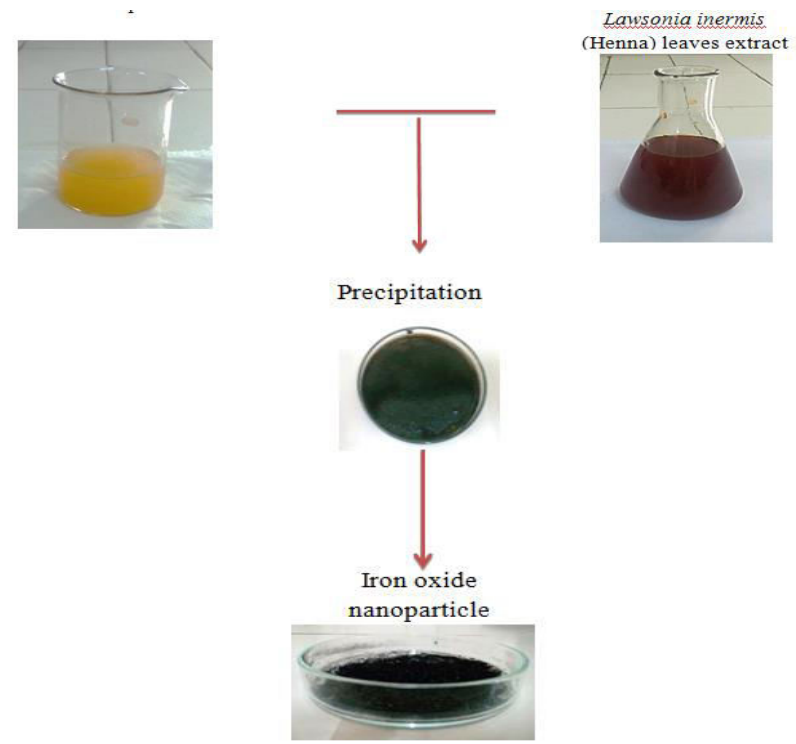

Fig.2: UV - Visible Spectroscopy analysis of green synthesized Iron oxide nanoparticle using Lawsonia inermis (Henna) leaves extract

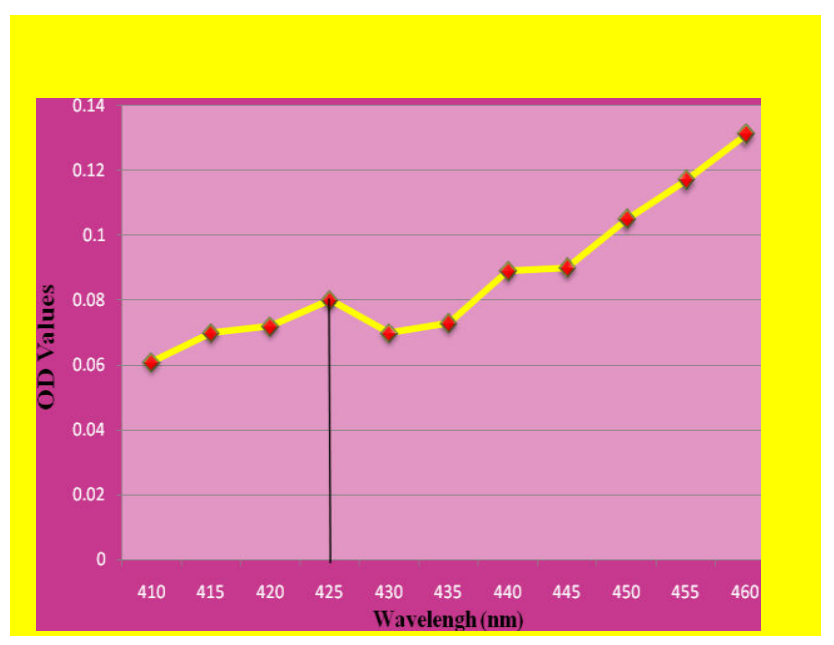

Fig.3: Fourier Transform Infrared Rays (FTIR) spectroscopy analysis

FTIR Spectroscopy was used to investigate the interactions between different components and changes in chemical compositions of the mixtures. FTIR measurements of the green synthesized iron oxide nanoparticle was carried out to identify the possible biomolecules responsible for the reduction, capping and efficient stabilization of the bio-reduced Iron nanoparticle. The results of FTIR analysis of Iron oxide nanoparticle synthesized using Henna leaves (Lawsonia inermis) are 
depicted in figure-2. The results of the study revealed the functional groups present in Iron oxide nanoparticle displays a number of absorption peaks, reflecting its complex nature.

The absorption peaks at $3414 \mathrm{~cm}^{-1}$ which is the characteristic of $\mathrm{N}-\mathrm{H}$ stretching vibrations indicates strong hydrogen bonding. The peaks at $424 \mathrm{~cm}^{-1}, 489 \mathrm{~cm}^{-1}, 553 \mathrm{~cm}^{-1}$, $604 \mathrm{~cm}^{-1}, 714 \mathrm{~cm}^{-1}$, and $766 \mathrm{~cm}^{-1}$, may be due to the presence of chemical bonding, crystal structure and relative intensities of carbonates. The peaks at $1604 \mathrm{~cm}^{-1}$ denotes the presence of $\mathrm{OH}$ group, peaks at $1595 \mathrm{~cm}^{-1}$ denotes the $\mathrm{C}=\mathrm{C}$ group and $1106 \mathrm{~cm}^{-1}$ is due to $\mathrm{C}-\mathrm{O}$ groups are observed as well as the bands from $3936.88 \mathrm{~cm}^{-1},-3782.57$ $\mathrm{cm}^{-1}, 3704.45 \mathrm{~cm}^{-1},-3641.15 \mathrm{~cm}^{-1}$ attributes to aliphatic C$\mathrm{H}$ stretching and bending modes. Bands at $3414.15 \mathrm{~cm}^{-1}$, $3395.83 \mathrm{~cm}^{-1}$ denotes $\mathrm{O}-\mathrm{H}$ stretching $\mathrm{H}$-bonding, alcohols and phenols. The band at $2928.07 \mathrm{~cm}^{-1}, 2872.13 \mathrm{~cm}^{-1}$ and $2271.28 \mathrm{~cm}^{-1}, 2226.91 \mathrm{~cm}^{-1}$ may be due to N-H group of amine. The results of FTIR spectrum of Iron oxide nanoparticle suggested that Iron oxide nanoparticle was surrounded by different organic molecules such as terpenoids, alcohols, ketones, aldehydes and carbolic acid that acts as reducing and capping agent provides stability to nanoparticle.

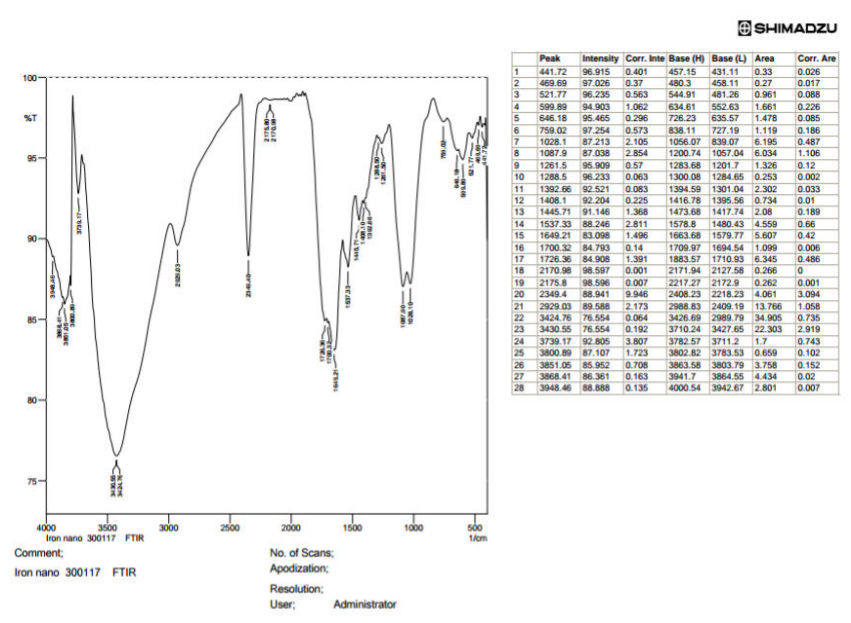

Fig. 4: FTIR analysis of green snthesized Iron oxide nanoparticle using Lawsonia inermis (Henna) leaves

\subsection{X-ray Diffraction}

The X-ray Diffraction (XRD) pattern (figure - 3) shows a high crystallinity of Iron sample level with diffraction angle range from $30-80^{\circ}$ at $2 \theta$ (degree). On examining XRD pattern of Iron oxide nanoparticle the prominent different peaks at $2 \theta=36^{\circ}, 38.5^{\circ}, 48^{\circ}$ and $62^{\circ}$. These peaks corresponds to (111), (200) and (202), (113) Bragg's reflections of the Face Centered Cubic (FCC) structure of Iron respectively. The size of the Iron oxide nanoparticle is also determined from X-ray line broadening using the Debye-Scherrer formula (Suresh et al., 2014).

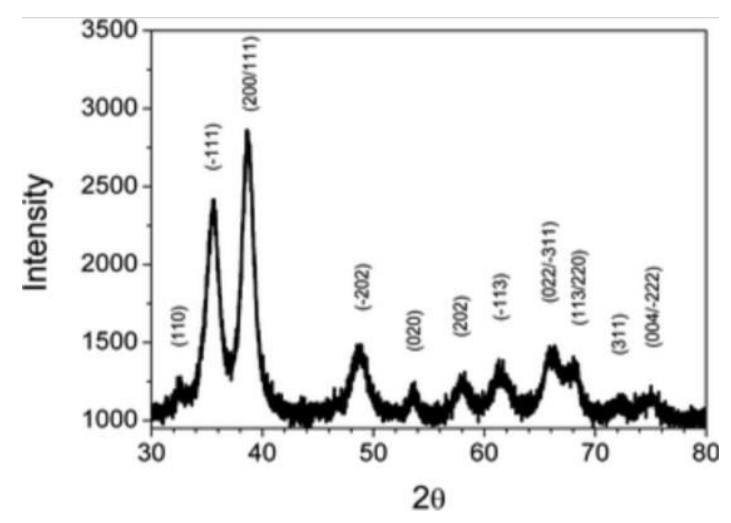

Fig.5: XRD analysis of green synthesized Iron oxide nanoparticle using Henna (Lawsonia inermis) leaves extract

\subsection{Scanning Electron Microscopy}

The results of the Scanning Electron Microscope (SEM) of green synthesized Iron oxide nanoparticle are depicted in Plate 3. The results of the study revealed that the size of the Iron oxide nanoparticle synthesized using Lawsonia inermis leaf extract is $2 \mu \mathrm{m}$ in diameter and the shape is found to be Hexagonal and agglomerates are also observed.

Plate 3. Scanning electron microscopic analysis of green synthesized Iron oxide nanoparticle using Lawsonia inermis (Henna) leaves

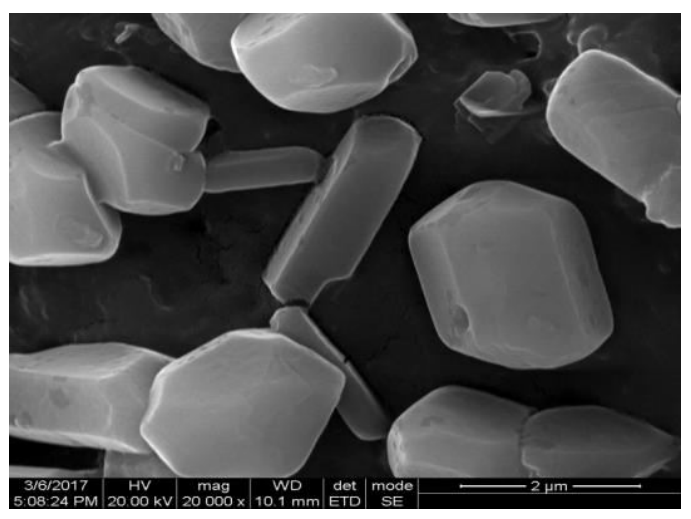

Fig.6: Antimicrobial activity of green synthesized Iron oxide nanoparticle using Henna (Lawsonia inermis) leaves extract

\subsection{Antibacterial Activity of Green Synthesized Iron Oxide Nanoparticle}

The results of antibacterial activity of Iron oxide nanoparticle using Henna leaves (Lawsonia inermis) extract against the bacterial isolates Escherichia coli and Staphyloccocus aureus are shown in Plate 4a, Tables 1a and $1 \mathrm{~b}$. The Iron oxide nanoparticle using Henna (Lawsonia inermis) leaves show the colour change from 
violet to light brown. Minimum Inhibitory Concentration (MIC) was determined by broth dilution technique using green synthesized iron oxide nanoparticle. The lowest concentration required to arrest the growth of bacteria is regarded as Minimum Inhibitory Concentration (i.e.) $500 \mu \mathrm{g} / \mathrm{ml}$. Thus, the Minimum Inhibitory Concentration of antibacterial activity of iron oxide nanoparticle was found to be $500 \mu \mathrm{g} / \mathrm{ml}$.

Plate 4a. Antibacterial activity of green synthesized Iron oxide nanoparticle of Lawsonia inermis (Henna) leaves extract (96 well titre plate Resazurin methodMIC)

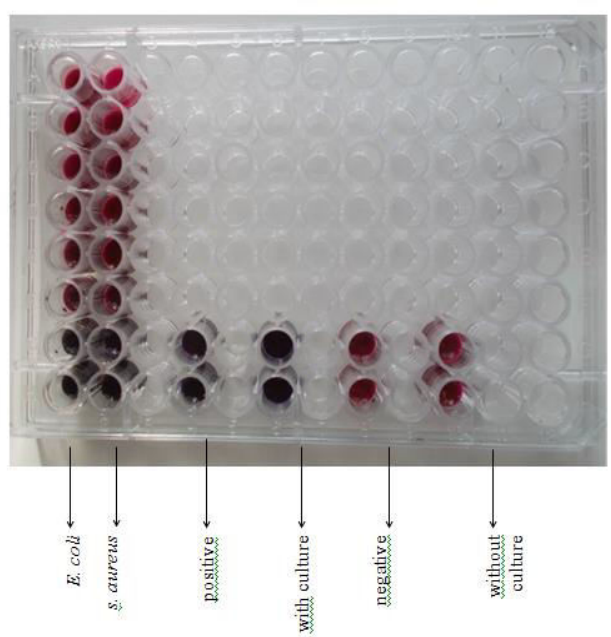

Fig.7: Antibacterial activity of green synthesized Iron oxide nanoparticle of Lawsonia inermis

Table 1(a): Antibacterial activity of green synthesized Iron oxide nanoparticle using Lawsonia inermis (Henna) leaves extract for Escherichia coli and staphylococcus aureus

\begin{tabular}{|c|c|c|c|c|c|c|c|c|c|c|c|}
\hline $\begin{array}{l}\text { S. } \\
\text { No }\end{array}$ & \begin{tabular}{|l|} 
Microor \\
ganisms/
\end{tabular} & \multicolumn{10}{|c|}{ Growth of inhibition } \\
\hline & & $\begin{array}{c}1 \\
\mathrm{mg}\end{array}$ & $\begin{array}{l}0.5 \\
\mathrm{mg}\end{array}$ & $\begin{array}{c}0.25 \\
\mathrm{mg}\end{array}$ & $\begin{array}{c}0.125 \\
\mathrm{mg}\end{array}$ & $\begin{array}{c}0.062 \\
\mathrm{mg}\end{array}$ & $\begin{array}{c}0.031 \\
\mathrm{mg}\end{array}$ & $\begin{array}{c}0.015 \\
\mathrm{mg}\end{array}$ & $\begin{array}{c}0.007 \\
\mathrm{mg}\end{array}$ & $\begin{array}{c}\text { Posi } \\
\text { tive } \\
\text { cont } \\
\text { rol } \\
10 \mu \mathrm{g}\end{array}$ & $\begin{array}{l}\mathrm{Cul} \\
\text { ture }\end{array}$ \\
\hline & $\begin{array}{l}\text { Nanopa } \\
\text { rticle }\end{array}$ & & & & & & & & & & \\
\hline 1 & E. coli & - & - & + & + & + & + & + & + & - & + \\
\hline 2 & S. aureus & - & - & + & + & + & + & + & + & - & + \\
\hline
\end{tabular}

(+) Positive activity- colour change occurs; (-) negative activity- no colour change occurs

Table 1(b): Minimum Inhibitory Concentration (MIC) of green synthesized Iron oxide nanoparticle on Escherichia coli and Staphylococcus aureus

\begin{tabular}{|l|c|}
\hline Microorganisms/sample & MIC Value (mg) (Nanoparticle) \\
\hline E. coli & $0.5 \mathrm{mg}$ \\
\hline Staphylococcus aureus & $0.5 \mathrm{mg}$ \\
\hline
\end{tabular}

\subsection{Antifungal activity of green synthesized Iron oxide nanoparticle}

The results of antifungal activity of green synthesized Iron oxide nanoparticle using Henna leaves (Lawsonia inermis) against the fungal strain Aspergillus niger and Mucor sp. are shown in Plate $4 \mathrm{~b}$ and table $1 \mathrm{c}$ and $1 \mathrm{~d}$. Iron oxide nanoparticle using Henna leaves (Lawsonia inermis) shows the colour change from violet to light brown.

The lowest concentration required to arrest the growth of fungus was regarded as Minimum Inhibitory Concentration (MIC) using green synthesized Iron oxide nanoparticle. The antifungal screening of Aspergillus niger and Mucor sp. revealed that both the fungal species showed good results and the Minimum Inhibitory Concentration was found to be $500 \mu \mathrm{g} / \mathrm{ml}$ in both of the fungal species.

Plate 4b. Antifungal activity of green synthesized Iron oxide nanoparticle of Lawsonia inermis (Henna) leaves extract (96 well titre plate Resazurin method-MIC)

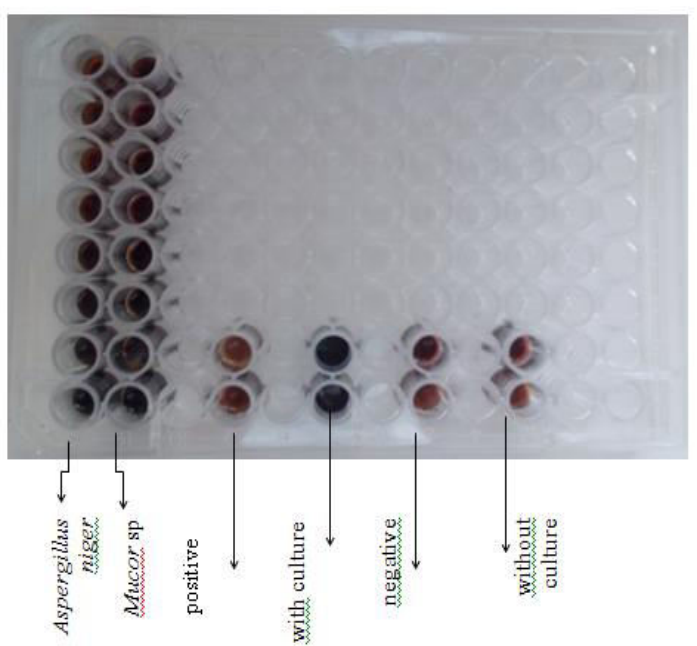

Fig.8: Antifungal activity of green synthesized Iron oxide nanoparticle of Lawsonia inermis

Table 1(c): Antifungal activity of green synthesized Iron oxide nanoparticle using Lawsonia inermis (Henna) leaves extract for Aspergillus niger and Mucor sp.

\begin{tabular}{|c|c|c|c|c|c|c|c|c|c|c|c|}
\hline S. & $\begin{array}{l}\text { Microor } \\
\text { ganisms/ }\end{array}$ & \multicolumn{10}{|c|}{ Growth of inhibition } \\
\hline & & $\begin{array}{c}1 \\
\mathrm{mg}\end{array}$ & $\begin{array}{l}0.5 \\
\mathrm{mg}\end{array}$ & $\begin{array}{c}0.25 \\
\mathrm{mg}\end{array}$ & $\begin{array}{c}0.125 \\
\mathrm{mg}\end{array}$ & $\begin{array}{c}0.062 \\
\mathrm{mg}\end{array}$ & $\begin{array}{c}0.031 \\
\mathrm{mg}\end{array}$ & $\begin{array}{c}0.015 \\
\mathrm{mg}\end{array}$ & $\begin{array}{c}0.007 \\
\mathrm{mg}\end{array}$ & $\begin{array}{c}\text { Posi } \\
\text { ti } \\
\text { ve } \\
\text { cont } \\
\text { rol } \\
10 \mu \mathrm{g}\end{array}$ & $\begin{array}{l}\text { Cult } \\
\text { ure }\end{array}$ \\
\hline & $\begin{array}{l}\text { Nanopa } \\
\text { rticle }\end{array}$ & & & & & & & & & & \\
\hline 1 & $\begin{array}{l}\text { Aspergill } \\
\text { usniger }\end{array}$ & - & - & + & + & + & + & + & + & - & + \\
\hline 2 & Mucorsp. & - & - & + & + & + & + & + & + & - & + \\
\hline
\end{tabular}


Table 1(d): Minimum Inhibitory Concentration (MIC) of green synthesized Iron oxide nanoparticle on Aspergillus niger and Mucor sp.

\begin{tabular}{|l|c|}
\hline Microorganisms/sample & $\begin{array}{c}\text { MIC Value (mg) } \\
\text { (Nanoparticle) }\end{array}$ \\
\hline A.niger & 0.5 \\
\hline Mucorsp. & 0.5 \\
\hline
\end{tabular}

\section{Discussion}

Nanotechnology plays a very important role in modern research and it is the most capable technology that can be applied in any field of interest. Its growing interest is in the therapeutic field for the ailments such as infection, cancer, allergy, diabetes and inflammation (Mekala et al., 2016). Technology has created an impressive increase in the production of nanomaterial in many sector of the society (Dedeh et al., 2013).

Iron oxide nanoparticles are synthesized from vapour deposition, electrochemical reduction, radiolysis Reduction, thermal decomposition, chemical reduction of Iron metal salt (Jayalakshmi et al., 2014). The use of these synthetic methods requires both strong and weak chemical reducing agents and protective agents like sodium borohydride, sodium citrate and alcohols. These agents are mostly toxic, flammable, cannot be easily disposed off due to environmental issues and also show a low production rate (Sharma et al., 2009; Bhui et al., 2009). It leads to in search of alternatives which could be ecofriendly and does not cause any harm to human and domestic animals. The cheapest and simplest method to synthesize nanomaterials is a biological method i.e., use of plants, bacteria, fungi, etc. The rate of reduction of metal ions using biological agents is found to be very much faster and also at ambient temperature and pressure conditions. Use of biological organisms such as microorganisms, plant extract or plant biomass could be an alternative to chemical and physical methods for the production of an eco-friendly manner of nanoparticle (Mason et al., 2012).

The study was further carried out to synthesize the Iron oxide nanoparticle. The change in colour from yellow to black of reaction mixture is due to Surface Plasmon Resonance phenomenon which provides a convenient indication of formation of Iron oxide nanoparticle (Tayyabanaseem et al., 2015).

Green synthesized Iron oxide nanoparticle using Lawsonia inermis leaf extract was further confirmed by studying the characterization of green synthesized Iron oxide nanoparticle such as UV - Vis Spectroscopy, FTIR, XRD and SEM. The study was further extended to characterize the green synthesized nanoparticle using FTIR spectroscopy. FTIR spectroscopy was used to investigate the interactions between different species and changes in chemical compositions of the mixtures. (Sewani and Qureshi, 2016).

The FTIR characterization is used to find the molecules and their functional group present in the green synthesized Iron oxide nanoparticle. The results of FTIR spectra of green synthesized Iron oxide nanoparticle revealed the presence of different functional groups like alcohol, alkane, alene, amine, nitro compound and acid ester. These functional groups play an very important role in reduction and stabilization process of the Iron oxide nanoparticle synthesis. The results of the above study are in the accordance with the work of Sewani and Qureshi (2016).

Formation of colour appearence is indicative of different functional groups and proteins present in Henna (Lawsonia inermis) leaves which could act as stabilizer (Senthil kumar and Sivakumar, 2014). The surface morphology and size of the nanoparticle were obtained by Scanning Electron Microscopy (SEM) analysis. The results of SEM showed that the green synthesized Iron oxide nanoparticle was hexagonal in shape. The size of Iron oxide nanoparticle synthesized using Henna leaves (Lawsonia inermis) was $2 \mu \mathrm{m}$ in diameter. The results of the study were supported by Johan et al. (2012) and Mekala et al. (2016).

Technique used to establish the metallic nature of particles provides information on translational symmetry size and shape of the unit cell from peak locations and information on electron density inside the unit cell, namely where the atoms are located from peak intensities. XRD patterns taken using powder X-ray diffractometer instrument in the angle range $10-70^{\circ}$ of the Iron oxide nanoparticle at $2 \theta$, scan axis $2: 1$ systematically. This is supported by the work of Caroling et al. (2015).

The XRD pattern shows a high crystallinity of Iron sample level with diffraction angle range from $30-80^{\circ}$ at $2 \theta$ (degree). On examining XRD pattern of Iron oxide nanoparticle the prominent different peaks at $2 \theta=36^{\circ}$, $38.5^{\circ}, 48^{\circ}$ and $62^{\circ}$. These peaks corresponds to (111), (200) and (202), (113) Bragg's reflections of the Face Centered Cubic (FCC) structure of Iron respectively. The size of the Iron nanoparticle is also determined from X-ray line broadening using the Debye-Scherrer formula (Suresh et al., 2014).

The presence of antimicrobial substances in the plants is well established as they have provided a source of inspiration for novel drug compound as plant derived medicines have made significant contribution towards human for the diseases treatment as done in the cases of Unani and Ayurvedic systems of medicines. A number of 
antibacterial and antifungal drugs available in the market produce many side effects; hence to improve the status of therapy, various ailments of plant extracts like Lawsonia inermis will be much useful (Tayyabanaseem et al., 2015). Therefore the study was further extended to evaluate the antimicrobial activity of both bacterial and fungal activity of green synthesized Iron oxide nanoparticle.

Iron oxide nanoparticles were effective in killing a range of bacterial pathogens involved in hospital acquired infections. However in comparison with nano Gold and nano Copper, higher concentrations of nano Iron oxide were to be required to achieve a bactericidal effect. It has been suggested that the reduced amount (between 3- and 20 -fold) of negatively charged peptidoglycans would make gram-negative bacteria less susceptible to such positively charged antimicrobials. A cell wall is present around the outside of the bacterial cell membrane and it is essential for the survival of bacteria. It is made from polysaccharides and peptides named peptidoglycan. In bacteria, there are two different types of cell walls (gram-positive and gramnegative). The names originate from the reaction of the cells with the gram's stain, a test long-employed for the classification of bacterial species. Gram-positive bacteria possess a thick wall containing many layers of peptidoglycan. Surfaces of Iron nanoparticle affect interaction directly with the bacterial outer membrane, causing the membrane to rupture and killing bacteria (Ipsa Subhankari et al., 2013). The result of antibacterial activity of green synthesized Iron oxide nanoparticle using Henna (Lawsonia inermis) leaf extract against two bacterial species E. coli and Staphylococcus aureus showed that though green synthesized Iron oxide nanoparticle was found to be efficient in inhibiting the growth of the bacterial isolates, which may be due to presence of tannins, protein, phenol and saponin biomolecules in Lawsonia inermis leaf extract. The use of plant extract with known antimicrobial properties can be of significant for therapeutic treatment. The values of antibacterial activity of green synthesized Iron oxide nanoparticle using Henna (Lawsonia inermis) leaf extract against E. coli and $S$. aureus are statisfically significant at $0.5 \%$ level. This is supported by the work of Shanmugam et al. (2014) and Jayanthi (2015).

The Iron oxide nanoparticle exhibited a potent antifungal activity against fungal strains. Iron oxide nanoparticles have remarkable potential antifungal activity in treating fungal infectious diseases. Fungal cells by having ergosterol in the membrane and by making various gradients between cytoplasmic membranes, can keep their membrane conformity might have been destroyed and causes the cell death.

It is clear that metallic nanoparticle have great potential in many different industries. The need for a process to synthesize such nanoparticle in a reliable and green way is becoming more promising. Current chemical and physical methods involve toxic chemicals and high temperatures that are not only dangerous to the environment but costly too. Numerous groups have focused on alternative ways of synthesizing nanoparticle as evidenced in the above study. Biological systems have been investigated in an effort to provide a sustainable, resource efficient and cheap method of synthesis. The field of biological production of metallic nanoparticle is relatively new and underexplored, however it shows a great potential in the biotechnology sector. There are many aspects of these biological methods to be discovered, and later manipulated, as the technology emerges (Thakkar et al., 2010).

\section{Conclusion}

To conclude from the results of the present study, that Lawsonia inermis aqueous leaf extract act as an agent to reduce the Iron oxide nanoparticle from ferrous sulphate solution. The green synthesized Iron oxide nanoparticles were characterized by, UV-Vis spectroscopy, FTIR, SEM and XRD. From the result of antimicrobial activity of green synthesized Iron oxide nanoparticle, it is clear to know that Iron nanoparticle synthesized from Lawsonia inermis leaves extract also have ability to inhibit the growth of various microorganisms Bacteria (Staphylococcus aureus and Escherichia coli) and Fungi (Aspergillus niger and Mucor sp.) and thus Iron oxide nanoparticle showed potential antioxidant property.

The development of functionalized green synthesized Iron oxide nanoparticle as therapeutic agents has generated great interest in both academy and industry. The present investigation reveals that the green synthesized Iron oxide nanoparticle extracted from Lawsonia inermis have medicinal applications, especially for anticancer profiling.

\section{Reference}

[1] Benzie, I.F.F and Strain, J.J. 1996. Ferric Reducing Ability of Plasma (FRAP) as a measure of antioxidant power : The FRAP assay. Anal. Biochem., 239 : 70-76.

[2] Bhui, B.H. Sahoo, D.K. Sarkar, G.P.P. De, S.P. and Mirsa, A. 2009. Green synthesis of Silver nanoparticle using latex of Jatophacurcas. Colloids surf. A: Physico chem. Eng. asp, 339: 134-139.

[3] Caroling, G. Mercy Ranjitham, A. Suja, R. and SunitaTiwari. 2013. Invitro evaluation of Antioxidant, Antimicrobial, Anticancer activities and characterization of Brassica oleracea, Var. Bortrytis. Leaves synthesized silver nanoparticle. International Journal of Pharmacy and Pharmaceutical Sciences. 5(4): 239-251.

[4] Dedeh, A. Ciutat, A. Delapierre, M.T. and Bourdineau, J.P. 2014. Impact of Gold nanoparticle on Zebrafish exposed to a spiked sediment, Nanotoxicology. 1(1):1-10.

[5] Habbal, O. A. A. A. Al-Jabri, and A. G. El-Heg, 2013, Antimicrobial properties of Lawsoniainermis (henna): a review, Australian journal of medical Herbalism, volume 19, no. 3, pp. 265 273.

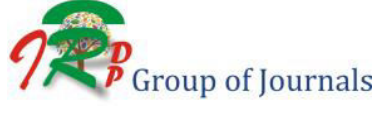


[6] Ipsa Subhankari. and Nayak, P.I. 2013. Synthesis of Copper nanoparticle using SyzgiumAromaticum (Cloves) aqueous extract by using green chemistry. World Journal of Nano Science and Technology, 2(1): 14-17.

[7] Jayalakshmi and Yogamoorthi, A. 2014. Green Synthesis of Copper oxide nanoparticle using aqueous of flowers of Cassia alata and particles characterization. International Journal of Nanomaterials and Biostructures, 4(2): 66-71.

[8] Jayanthi, D. 2015. Biosynthesis, characterization and antibacterial activity of Zinc oxide nanoparticle. (M.Sc., Dissertation) JBAS College, Chennai, 7-13.

[9] Johan, M.R. Wen, K.S. Hawari, N. and Aznan, N.A.K. 2012 Synthesis and characterization of copper iodide nanoparticle via chemical route. International Journal of Electrochemical Science , 12(3):4942-4950.

[10] Mason, C., Vivekandha, S., Misra, M., Kumar, A. and Mohanty. 2012. Switch grass (Panicumvirgatum) extract medicated green synthesis of silver nanoparticle. World Journal of Nano science and Engineering, 2:47-52.

[11] Mekala, J., Rajan, M.R., Ramesh. R. 2016. Green synthesis and characterization of Copper nanoparticle using Tulsi (Ocimum sanctum) leaf extract. Biological Science, 5(2) :25-31.

[12] Rodriguez, J.A., Fernandez-Garcia, M; (Eds.) 2007. Synthesis, Properties, Applications of Oxide Nanoparticle. Whiley: New Jersy.104, 4063..

[13] Senthilkumar, S.R. and Sivakumar, T. 2014. Green Tea (Camellia sinensis) mediated synthesis of Zinc oxide (Zno) nanopartilces and studies on their antimicrobial activities. International Journal of Pharamacy and Pharmaceutical Sciences, 6(6): 55-60.
[14] Sewani, S and Qureshi, M. 2016. Antimicrobial activity of Neem, Clove, Curry leaves, Cardamom, Tulsi stem and Tulsi leaves. International Research Journal of Biological Sciences, 5(1): 42-46.

[15] Shanmugam, B., Shanmugam, K.R., Ravi, S., Subbaiah, V.G., Mallikarjuna, K. and Reddy, K.S. 2014. Antibacterial activity and Phytochemical screening of Phyllanthusniruriin ethanolic, methanolic and aqueous extracts. Int. J. Pharm. Sci. Rev. Res., 27 (2): 85-89.

[16] Sharma, N.C., Sahi, S.V., Nath, S., Parsons, J.G., Torresdey, G.J.L. and Pal, T. 2009. Synthesis of plant-mediated gold nanoparticle and catalytic role of Biomatrix-Embedded nanomaterials. Environment Science Technology, 41: 5137-5142.

[17] Sundararaj. 1997. Practical manual of Microbiology. 3(3):27-50

[18] Suresh Y, Annapurna S, Bhikshamaiah G and Singh A.K, 2014. Copper Nanoparticle Green synthesis and Characterization. International Journal of Scientific \& Engineering Research. 5( 3 ): 156-160.

[19] TayyabaNaseem, Muhammad, and Akhyarfarrukh, 2015. Antibacterial activity of green synthesis of iron nanoparticle using Lawsoniainermis and Gardianajasminoides leaves extract Hindawi publishing corporation, Journal of chemistry, volume, Article ID 912342, 7 pages.

[20] Thakkar, K.N., Mhatre, S.S., Parikh, R.Y. 2010. Biological synthesis of metallic nanoparticle. Nanomedicine, 6 (2): 257-262.

[21] Willard, M.A., Kurihara, L.K., Carpenter, E.E., Calvin, S. and Harris, V.G. 2014. Chemically prepared magnetic nanoparticle. International Materials Reviews, 125-170.

[22] Wykoff, R. W. G. crystal structures , $2^{\text {nd }}$ edition; wiley: new york, 1964. 